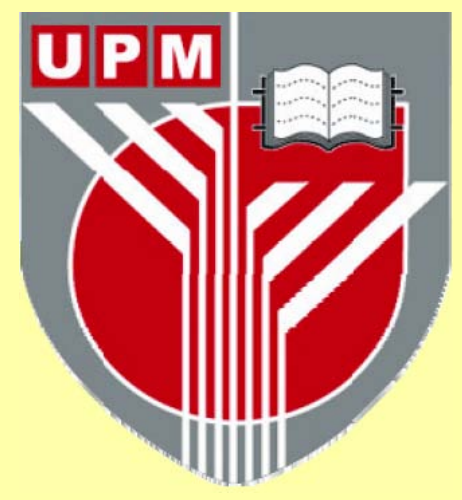

UNIVERSITI PUTRA MALAYSIA

FATIGUE BEHAVIOUR OF OIL PALM FRUIT BUNCH FIBRE/EPOXY AND CARBON FIBRE/EPOXY COMPOSITES

ANIZAH KALAM

FK 20033 
FATIGUE BEHAVIOUR OF OIL PALM FRUIT BUNCH FIBRE/EPOXY AND CARBON FIBRE/EPOXY COMPOSITES

By

ANIZAH KALAM

Thesis Submitted to the school of Graduate Studies, Universiti Putra Malaysia, in Fulfilment of the Requirement for the Degree of Master of Science 
Abstract of thesis presented to the Senate of Universiti Putra Malaysia in partial fulfilment of the requirements for the degree of Master of Science

\title{
FATIGUE BEHAVIOUR OF OIL PALM FRUIT BUNCH FIBRE/EPOXY AND CARBON FIBRE/EPOXY COMPOSITES \\ By
}

ANIZAH KALAM

April 2003

\author{
Chairman: Professor Ir. Dr. Barkawi Bin Sahari \\ Faculty : Engineering
}

Tensile test on unidirectional Oil Palm Fruit Bunch (OPFB) fibre/epoxy composite and unidirectional Carbon Fibre (CF)/epoxy composite were conducted to determine their ultimate tensile stress, the Young's modulus and elongation at fracture. Two different fibre volume fractions of $35 \%$ and $55 \%$ were studied in OPFB fibre/epoxy composite. The fibre volume fraction of CF/epoxy composite studied was $42 \%$. The ultimate tensile stress determined from the tensile tests were then used to determine the maximum stress levels, $\mathrm{S}_{\max }$ of fatigue tests for $\mathrm{CF}$ and OPFB fibre/epoxy composites.

Two parameters were studied in fatigue test, which were stress ratio, $R(0.1$ and 0.5$)$ and fibre volume fraction, $\mathrm{V}_{\mathrm{f}}(35 \%$ and $55 \%)$. All Fatigue tests were performed at constant stress amplitude, at an air-conditioned room temperature of $20^{\circ} \mathrm{C}$ and at a frequency of $20 \mathrm{~Hz}$. Observation on fractured surface of tensile and fatigue tested specimens were also done. 
The ultimate tensile stress of CF/epoxy composite is $247.0 \mathrm{MPa}$. OPFB fibre/epoxy composite with fibre volume fraction of $35 \%$ and $55 \%$ have ultimate tensile stress of 47.8 MPa and 46.1 Mpa, respectively.

The observation on fractured surface of tensile tested specimens showed that $\mathrm{CF}$ and OPFB fibre/epoxy composites failed in a brittle manner. Fatigue behaviour of CF/epoxy composite shows a reduction in fatigue resistance with decreasing stress ratio. Three specimens survived 1 million cycles, which were cycled at stress ratio of 0.1 and maximum stress level, $S_{\max }$ of 0.65 . There was no indication of fatigue limit shown by S-N curves for OPFB fibre/epoxy composite for both fibre volume fractions. However the S-N curves of OPFB fibre/epoxy composite showed a decrease of fatigue resistance with the increase of fibre volume fraction from $35 \%$ to $55 \%$

Two types of fractured surface were observed on the CF/epoxy composite failed in fatigue test, which were brittle and delamination. Meanwhile the fractured surface of OPFB fibre/epoxy composite showed brittle, delamination and fibre pull-out. 
Abstrak tesis yang dikemukakan kepada Senat Universiti Putra Malaysia sebagai memenuhi sebahagian dari keperluan untuk ijazah Master Sains

KELAKUAN LESU BAGI KOMPOSIT SERAT TANDAN KELAPA SAWIT/EPOXY DAN KOMPOSIT SERAT KARBON/EPOXY

Oleh

ANIZAH KALAM

April 2003

\section{Pengerusi: Profesor Ir. Dr. Barkawi Bin Sahari \\ Fakulti : Kejuruteraan}

Ujian tegangan telah dijalankan keatas komposit berserat searah dari tandan kelapa sawit (OPFB)/epoxy dan serat karbon (CF)/epoxy untuk menentukan tegasan tegangan muktamad, modulus Young dan pemanjangan pada masa patah. Bahan komposit OPFB/epoxy yang dikaji mempunyai pecahan isipadu serat yang berbeza iaitu $35 \%$ dan 55\%. Manakala pecahan isipadu serat bagi komposit CF/epoxy adalah $42 \%$. Tegasan tegangan muktamad yang telah didapati dari ujian tegangan akan digunakan untuk menentukan paras tegasan maksima yang dikenakan dalam ujian kelesuan bagi kedua-dua komposit.

Dua parameter yang dikaji dalam ujian kelesuan adalah nisbah tegasan, $\mathrm{R}$ (0.1 dan 0.5) dan juga pecahan isipadu serat, $\mathrm{V}_{\mathrm{f}}(35 \%$ dan $55 \%)$. Semua ujian kelesuan dijalankan pada amplitud tegasan yang malar, di dalam bilik berpendingin hawa pada suhu $20^{\circ} \mathrm{C}$ dan frekuensi $20 \mathrm{~Hz}$. Pemerhatian ke atas bahagian permukaan spesimen yang patah dalam ujian tegangan dan ujian kelesuan juga dilakukan. 
Nilai tegasan tegangan muktamad yang didapati dari ujian tegangan bagi komposit CF/epoxy adalah 247.0 MPa. Manakala komposit OPFB fibre/epoxy yang mempunyai pecahan isipadu serat $35 \%$ dan $55 \%$ masing-masing menunjukkan nilai tegasan tegangan muktamad 47.8 $\mathrm{MPa}$ dan $46.1 \mathrm{MPa}$.

Pemerhatian keatas bahagian permukaan yang patah dalam ujian tegangan menunjukkan komposit CF/epoxy dan OPFB/epoxy patah secara rapuh. Kelakuan kelesuan bagi komposit CF/epoxy menunjukkan pengurangan dalam rintangan kelesuan terhadap penurunan nisbah tegasan. Tiga spesimen yang dikitar pada nisbah tegasan 0.1 dan paras tegasan maksimum 0.65 telah bertahan tanpa patah sehingga 1 juta kitaran. Tiada tanda had kelesuan ditunjukkan oleh lengkuk S-N bagi kedua-dua komposit OPFB/epoxy. Walaubagaimanapun lengkuk S-N bagi komposit OPFB/epoxy menunjukkan pengurangan rintangan kelesuan terhadap pertambahan pecahan isipadu serat dari $35 \%$ ke $55 \%$.

Komposit CF/epoxy yang patah dalam ujian kelesuan menunjukkan dua jenis permukaan patah iaitu secara rapuh dan sedikit tanda penyahlapisan. Manakala komposit OPFB/epoxy menunjukkan permukaan patah secara rapuh, sedikit penyahlapisan dan juga lolosan serat. 


\section{ACKNOWLEDGEMENTS}

Through the completion of the project many people have helped in its development and I would like to acknowledge their valued suggestions and comments. Specifically, I wish to express my profound appreciation and gratitude to the chairman of the supervisory committee, Professor Dr. Barkawi Sahari for his supervision, guidance, constructive suggestions, comments and his valuable time spent during the discussion.

A particular note of thanks is also given to the members of the supervisory committee, Associate Professor Dr. Yousif A. Khalid and Dr. Wong Shaw Voon for their guidance, suggestions and comments throughout the duration of the project.

I would also like to thank Tuan Haji Saharani for his technical expertise, guidance and assistance in using the Instron machine to perform the tests for this study. And also my appreciation to Wildan for his assistance during the test was carried out and to Ahmad Saifudin for his help and willingness to give some ideas in preparing the specimen's mould.

Many thanks are also extended to all the friends in Universiti Telnologi MARA and Universiti Putra Malaysia who contributed in giving ideas, suggestions and comments to this project.

Finally, and most importantly, I would like to express my deep gratitude to my husband, my sons and my daughter for their patience, love and full support, which allowed this report to be completed. 
I certify that an Examination Committee met on $1^{\text {st }}$ April 2003 to conduct the final examination of Anizah Kalam on her Master of Science thesis entitled "Fatigue Behaviour of Oll Palm Fruit Bunch Fibre/Epoxy and Carbon Fibre/Epoxy Composites" in accordance with the Universitı Pertanian Malaysia (Higher Degree) Act 1980 and Unıversıtı Pertanian Malaysıa (Higher Degree) Regulatıons 1981 The Committee recommends that the candidate be awarded the relevant degree Members of the Examination Committee are as follows

Mageed Hamouda, Ph.D.

Associate Professor,

Department of Mechanical and Manufacturıng Engıneerıng,

Faculty of Engineering,

Unıversitı Putra Malaysıa

(Chairman)

\section{Barkawi Sahari, Ph.D.}

Professor,

Department of Mechanıcal and Manufacturıng Engıneerıng,

Faculty of Engineerıng,

Unıversitı Putra Malaysıa

(Member)

\section{Yousif A. Khalid, Ph.D.}

Associate Professor,

Department of Mechanıcal and Manufacturıng Engıneerıng,

Faculty of Engineerıng,

Unıversitı Putra Malaysıa

(Member)

\section{Wong Shaw Voon, Ph.D.}

Department of Mechanical and Manufacturıng Engıneerıng,

Faculty of Engineerıng,

Unıversıtı Putra Malaysıa

(Member)

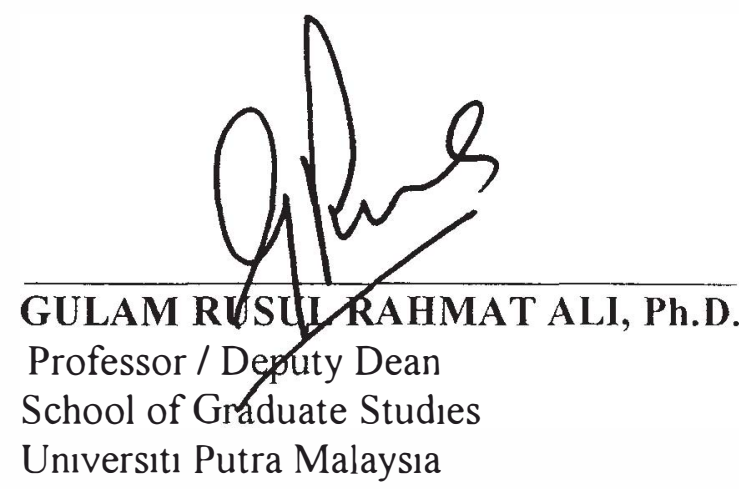

Date $11 \hat{A}^{\prime \prime}, 2003$ 
This thesis submitted to the Senate of Universiti Putra Malaysia has been accepted as fulfilment of the requirement for the degree of Master of Science. The members of the Supervisory Committee are as follows:

\section{Barkawi Bin Sahari, Ph.D.}

Professor,

Department of Mechanical and Manufacturing Engineering,

Faculty of Engineerring,

Universiti Putra Malaysia.

(Member)

Yousif A. Khalid, Ph.D.

Associate Professor,

Department of Mechanical and Manufacturing Engineering,

Faculty of Engineering,

Universiti Putra Malaysia.

(Member)

\section{Wong Shaw Voon, Ph.D.}

Department of Mechanical and Manufacturing Engineering,

Faculty of Engineerring,

Universiti Putra Malaysia.

(Member)

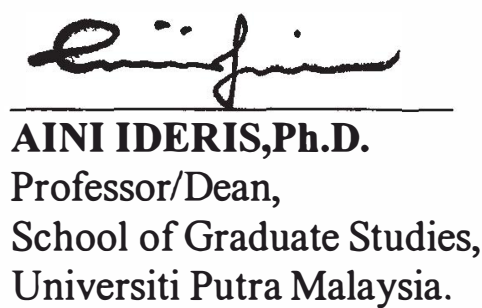

Date: 115 AUं 2003 


\section{DECLARATION}

I hereby declare that the thesis is based on my original work except for quotations and citations, which have been duly acknowledged. I also declare that it has not been previously or concurrently submitted for any other degree at UPM or other institutions.

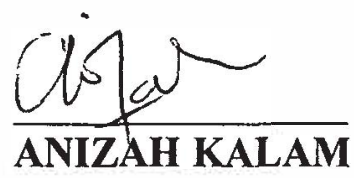

Date: $18 / 0: 03$ 


\section{TABLE OF CONTENTS}

Page

ABSTRACT

ii

ABSTRAK

iv

ACKNOWLEDGEMENTS

vi

APPROVALS

vii

DECLARATION

viii

LIST OF TABLES

xiii

LIST OF FIGURES

xiv

NOMENCLATURE

xvii

\section{CHAPTER}

1 INTRODUCTION

2 LITERATURE REVIEW 11

2.1 General 11

2.2 Behaviour of Unidirectional Composites 12

2.2.1 Factors Which Determine the Properties 14

2.2.2 Longitudinal Strength 15

2.2.3 Young's Modulus 19

2.3 Fatigue Behaviour of Composite Materials 20

2.3.1 Cyclic Stress-strain Behaviour 24

2.3.2 Consequences of Cyclic Loading on the Strength, Stiffness and Life $\quad 27$

2.4 Failure Mechanism 29

2.5 Fatigue Test Method 32

2.5.1 Load Control 33

2.5.2 Strain Control 34

2.5.3 Fatigue Test Parameters 36

2.6 Empirical Relations for Fatigue Failure 37

2.7 Scatter and Statistical Aspects in Fatigue 39

2.8 Related Previous Work 42

2.8.1 The Effect of Fibre Volume Fraction on Fatigue Performance 42

2.8.2 The Effect of Temperature on Fatigue Life of Composite 
2.8.3 The Influence of Frequency on Fatigue Life of Composite

2.8.4 The Effect of Stacking Sequence and Fibre Orientation on Fatigue Strength

2.8.5 Fatigue Behaviour of Polymer-based Composites 48

2.8.6 Relation between Failure Mechanisms and Fatigue Life 52

2.8.7 Tensile Properties of Polypropylene-oil Palm Empty Fruit Bunch-glass Fibre Hybrid Composites

2.8.8 Tensile Fatigue Behaviour of Epoxy 56

2.9 Discussion 57

3 METHODOLOGY 58

3.1 Materials Description 58

3.2 Specimen Preparation 59

3.3 Tests Description $\quad 62$

3.3.1 Tensile Test 63

3.3.2 Fatigue Test 64

3.4 Discussion 66

4 TENSILE TESTS RESULT AND DISCUSSION 67

4.1 Tensile Test Data 67

4.2 Stress-strain Curves 70

4.3 A Comparison of Stress-strain Curves 75

4.4 Discussion 76

5 FATIGUE TESTS RESULT AND DISCUSSION 77

5.1 Fatigue Tests Profile $\quad 77$

5.2 Fatigue Tests Data for CF/epoxy Composite 79

5.3 The S-N Curves for CF/epoxy Composite 81

5.4 Fatigue Tests Data for OPFB Fibre/epoxy Composite 85

5.5 The S-N Curves for OPFB Fibre/epoxy Composite 88

5.6 A Comparison of Fatigue Behaviour 92

5.7 The Effect of Stress Ratio, R 94

5.8 The Effect of Fibre Volume Fraction, $V_{\mathrm{f}} \quad 96$

5.9 Observation on Fractured Surface for CF/epoxy Composite Specimens

5.10 Observation on Fractured Surface for OPFB Fibre/epoxy Composite Specimens 
$\begin{array}{ll}5.11 \text { Discussion } & 106\end{array}$

6 GENERAL DISCUSSION 107

$\begin{array}{lll}6.1 & \text { Objectives } & 107\end{array}$

$\begin{array}{ll}6.2 & \text { Fabrication Method } \\ & 108\end{array}$

$\begin{array}{lll}6.3 & \text { Experimental Work } & 109\end{array}$

$\begin{array}{lll}6.4 & \text { Test Procedure } & 110\end{array}$

$\begin{array}{lll}6.5 & \text { Test Results } & 110\end{array}$

$\begin{array}{lll}6.6 & \text { Sources of Error } & 111\end{array}$

7 CONCLUSIONS AND RECOMMENDATIONS 112

$\begin{array}{lll}7.1 \text { Conclusions } & 112\end{array}$

$\begin{array}{lll}7.2 & \text { Recommendations } & 116\end{array}$

$\begin{array}{ll}\text { REFERENCES } & 117\end{array}$

$\begin{array}{ll}\text { APPENDICES } & 121\end{array}$

$\begin{array}{ll}\text { VITA } & 135\end{array}$ 


\section{LIST OF TABLES}

Table

Title

Page

2.1 : Constants in S-N representation of composite laminates

2.2 : The parameters of $\mathrm{K}$ and $\mathrm{c}$ for various laminates

2.3 : The fatigue test conditions of CFRP at frequency of $50 \mathrm{~Hz}$

2.4 : Fatigue properties of CFRP as a function of frequency

2.5 : The fatigue test conditions of CFRP at frequency of $50 \mathrm{~Hz}$

2.6 : Properties of the materials and static test result

2.7 : Mechanical properties of carbon fibre and neat resins

2.8 : The proportion of OPFB fibre/glass fibre

2.9 : Static properties of the tested specimens

3.1 : The properties of OPFB fibre/PP composite

3.2 : Particulars of the tested materials

3.3 : The particulars for fatigue test of $\mathrm{R}=0.1$

4.1 : Tensile tests result of all the materials tested

4.2 : The calculated mean $\sigma_{\text {ult }}$ according to Weibull distribution

5.1 : Fatigue tests data for $\mathrm{CF} /$ epoxy composite

5.2 : The $\mathrm{m}$ and $\mathrm{b}$ parameters for $\mathrm{S}-\mathrm{N}$ curves of CF/epoxy composite

5.3 : The parameters of $\mathrm{K}$ and $\mathrm{c}$ for two different stress ratios

5.4 : Fatigue tests data for OPFB fibre/epoxy composite 86

5.5 : The $m$ and $b$ parameters of OPFB fibre/epoxy composite 91

5.6 : The $\mathrm{K}$ and c parameters of OPFB fibre/epoxy composite 92

5.7 : The $m$ and $b$ parameters for CF/epoxy composite and OPFB fibre/epoxy composite

5.8 : The parameters of $\mathrm{K}$ and $\mathrm{c}$ for $\mathrm{CF} /$ epoxy composite and OPFB fibre/epoxy composite

7.1 : The elastic properties of the materials tested

7.2 : The fatigue constants of the materials tested 


\section{LIST OF FIGURES}

Figure Title Page

1.1 : Typical S-N curve fatigue life curve 6

2.1 : Schematic representation of unidirectional composite 12

2.2 : Longitudinal stress-strain diagrams for hypothetical composites 17

2.3 : Stress-strain curves of different unidirectional composites 18

2.4 : Stress-strain curves for CF/PEEK laminates 18

2.5 : S-N curves for 1045 steel and 2014-T6 aluminium 22

2.6 : Tension-tension S-N curves for unidirectional composite 22

2.7 : Schematic representation of S-N curves 23

2.8 : Effect of stress ratio on fatigue strength of unidirectional composites, XAS/914 24

2.9 : Schematic hysteresis loops at 1 cycle and $\mathrm{N}$ cycles 25

2.10 : Hysteresis loop diagram, for composite under fatigue testing 27

2.11 : The three characteristic stages of damage of composites 28

2.12 : Damage mode during fatigue life 29

2.13 : Micro-level Failure Mechanism 30

2.14 : Load-controlled testing 34

2.15 : Strain-controlled testing 35

2.16 : Fluctuating tension stress cycle in sine waveform 36

2.17 : S-N curve for E-glass/913 $\left[\left( \pm 45,0_{2}\right)_{2}\right]_{s}$ laminate 37

2.18 : Influence of glass content on axial fatigue strength 42

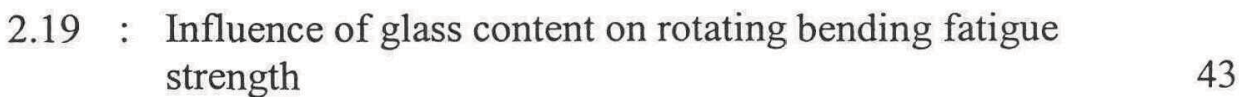

2.20 : S-N curve for unidirectional graphite epoxy composite 43

2.21 : Temperature effect on fatigue strength of CFRP 44

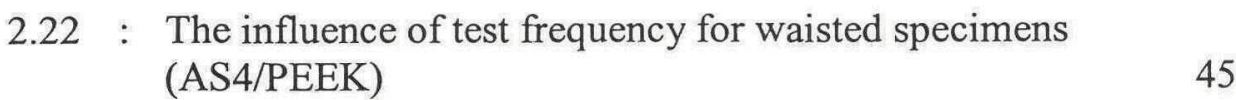

2.23 : Effect of reinforcement scheme on fatigue strength of
CFRP

2.24 : Comparison of stress-life curves for three fibre composites 48 
2.25 : Stress-strain curves for carbon epoxy and carbon nylon 49

2.26 : Normalised S-N data for the carbon/epoxy composites 50

2.27 : Fatigue behaviour of carbon fibre composite 51

2.28 : Effect of failure mechanisms on fatigue lives of the carbon/epoxy 52

2.29 : Tensile strength as a function of OPFB fibre loading 54

2.30 : Tensile modulus as a function of OPFB loading 55

2.31 : S-N curve of Hercules 3501-6 Epoxy at room temperature 57

3.1 : Oil palm fibre received from Sabutek (M) Sdn. Bhd 59

3.2 : Dimension of CF/epoxy composite specimen 60

3.3 : Dimension of OPFB fibre/epoxy composite specimen 61

3.4 : Straightening process 61

3.5 : OPFB fibre/epoxy composite specimens for tensile and fatigue test 63

3.6 : Instron 8500 Machine 64

3.7 : An example of stress cycle performed on CF/epoxy composite $(\mathrm{R}=0.1) \quad 65$

4.1 : A bar graph of coefficient of variation 68

4.2 : A comparison of experimental CF/epoxy composite stressstrain curve with the literature 71

4.3 : Stress-strain curve of epoxy 72

4.4 : Stress-strain curves of OPFB fibre/epoxy composite 74

4.5 : A comparison of stress-strain curves for all materials 75

5.1 : Fatigue test profile of CF/epoxy composite for $\mathrm{R}=0.1 \quad 78$

5.2 : Fatigue test profile of OPFB fibre/epoxy composite for $\mathrm{R}=78$ 0.1

5.3 : The $\mathrm{S}-\mathrm{N}$ data for $\mathrm{CF} /$ epoxy composite at $\mathrm{R}=0.1 \quad 80$

5.4 : The $\mathrm{S}-\mathrm{N}$ data for $\mathrm{CF} /$ epoxy composite at $\mathrm{R}=0.5 \quad 80$

5.5 : Stress-life curves for CF/epoxy composite 81

5.6 : Normalised stress-life diagram of CF/epoxy composite 83

5.7 : The curve-fitting line of $\log \mathrm{S}-\log \mathrm{N}$ for CF/epoxy composite

5.8 : The S-N data for OPFB fibre/epoxy composite with $\mathrm{V}_{\mathrm{f}}=$ $35 \%, \mathrm{R}=0.1$

5.9 : The S-N data for OPFB fibre/epoxy composite with $\mathrm{V}_{\mathrm{f}}=$ $35 \%, \mathrm{R}=0.5$ 
5.10 : The S-N data for OPFB fibre/epoxy composite with $\mathrm{V}_{\mathrm{f}}=$ $55 \%, \mathrm{R}=0.1$

5.11 : Stress-life curves for OPFB fibre/epoxy composite 89

5.12 : Normalised S-N data for OPFB fibre/epoxy composite 90

5.13 : The curve-fitting line of $\log \mathrm{S}-\log \mathrm{N}$ for OPFB fibre/epoxy composite $\quad 92$

5.14 : A comparison of S-N curves 93

5.15 : The normalised stress-life curves as a comparison 95

5.16 : The $\log \mathrm{S}-\log \mathrm{N}$ diagram for CF/epoxy composite and OPFB fibre/epoxy composite 97

5.17 : The Fractured surface of CF/epoxy specimen failed in 99

5.18 : The Fractured surface of CF/epoxy specimens failed in fatigue test $\left(<10^{5}\right.$ cycles $) \quad 100$

5.19 : The Fractured surface of CF/epoxy specimens failed in fatigue test $\left(>10^{5}\right.$ cycles)

5.20 : The gauge length section of a CF/epoxy specimen survived $10^{6}$ cycles

5.21 : The fractured OPFB fibre/epoxy composite specimen after tensile test

5.22 : The fractured surface of OPFB fibre/epoxy composite specimens failed in tensile test $\left(V_{\mathrm{f}}=35 \%\right)$

5.23 : The fractured surface of OPFB fibre/epoxy composite specimens failed in fatigue test $\left(\mathrm{V}_{\mathrm{f}}=35 \%\right)$

5.24 : The fractured surface of OPFB fibre/epoxy composite specimen failed in tensile test $\left(\mathrm{V}_{\mathrm{f}}=55 \%\right)$

5.25 : The fractured surface of OPFB fibre/epoxy composite specimen failed in fatigue test $\left(\mathrm{R}=0.1, \mathrm{~V}_{\mathrm{f}}=35 \%\right)$ 


\section{NOMENCLATURE}

FRP Fibre Reinforced Plastics.

EFB Empty Fruit Bunch.

PMC Polymer Matrix Composites.

PEEK Poly-ether-ether-ketone.

PPS Polyphenylene Sulfide.

CFRP Carbon fibre reinforced plastic.

$\mathrm{E}_{1}, \mathrm{E}_{2}, \mathrm{E}_{3} \quad$ Axial moduli (principal material directions)

$v_{12}, v_{13} \quad$ Axial Poisson's ratio.

$v_{23} \quad$ Transverse Poisson's ratio.

$\mathrm{G}_{12}, \mathrm{G}_{13} \quad$ Axial shear moduli.

$\mathrm{G}_{23} \quad$ Transverse shear moduli.

$\varepsilon_{1}, \varepsilon_{2}, \varepsilon_{3} \quad$ Axial strain (principal material directions).

$\sigma_{1}, \sigma_{2}, \sigma_{3}$ Axial stress (principal material directions).

$\mathrm{P} \quad$ Force

$\mathrm{m}, \mathrm{f}, \mathrm{c} \quad$ Subscripts $\mathrm{m}, \mathrm{f}$, and $\mathrm{c}$ refer to matrix, fibre and composite respectively

$\mathrm{W}_{\mathrm{m}} \quad$ Matrix weight fraction

$\mathrm{W}_{\mathrm{f}} \quad$ Fibre weight fraction

$\mathrm{W}_{\mathrm{c}} \quad$ Composite weight fraction

$\mathrm{V}_{\mathrm{m}} \quad$ Matrix volume fraction

$\mathrm{V}_{\mathrm{f}} \quad$ Fibre volume fraction

$\mathrm{V}_{\mathrm{c}} \quad$ Composite volume fraction

$\rho \quad$ Density.

$\sigma_{\text {ult }} \quad$ Ultimate tensile stress.

$\mathrm{R} \quad$ Stress ratio.

$\mathrm{S}_{\max } \quad$ Maximum stress level

$\mathrm{S} \quad$ Maximum applied stress

$\mathrm{N}_{\mathrm{f}} \quad$ Number of cycles to failure

CF Carbon Fibre

OPFB Oil Palm Fruit Bunch 


\section{CHAPTER 1}

\section{INTRODUCTION}

The present trend in the design of engineering components is towards using fibrous composite especially for structural applications in the aircraft and automotive industries. These industries need materials that are light in terms of weight but stiff in terms of strength, which is synonymous with composite materials. Amongst the popular form of fibres used are glass, carbon, boron and kevlar as reinforcing materials in fibre reinforced plastics (FRP), which have been widely accepted as materials for structural and non-structural applications.

In Malaysia, these fibres are generally imported in the form of woven roving, chopped strand mat and filament wind roving. However, these materials are very expensive and their use is justified only in aerospace applications. Mallick (1991) has stated one major obstacle to the widespread use of advanced composites is their costs. Therefore natural fibres like banana, cotton, sisal, coir, oil palm empty fruit bunch and jute have attracted the attention of many researchers as an altemative fibre especially for application in consumer goods, low-cost housing and other civil structures.

At the same time, the recent trend in environmental awareness has contributed to a great interest in the development, improvement and use of natural fibres as the reinforcing materials in polymeric composites. Ray et. al (2001) have stated that the attractive features of natural fibres are their low cost, lightweight, high specific modulus, renewability and biodegradability. Composites reinforced with such 
natural fibres have been the subject of intense study for low cost application in contrast to the synthetic fibre-reinforced composites.

According to Stowell (2001) Malaysia produces 16.5 million tonnes of oil palm fruit bunch (OPFB) fibre processed in oil palm mill a year. Based on this figures, Malaysia has a great potential in turning its abundant supply of oil palm industry byproducts into value-added products such as using the OPFB fibre as reinforcement or fillers in composite material. Therefore a lot of research work and studies need to be done on this to provide sufficient information of the material.

Before discussing any further about this project some understanding on several keywords such as composite, carbon fibre, oil palm fruit bunch, thermoset polymer and fatigue behaviour must be acquired. The word composite is always related to a newly developed or modern material but the fact is composites have been used since the beginning of human civilisation in the form of natural resources. Natural resources such as wood, bamboo and rattan are known as natural composite or traditional composite. The advantages obtained from these natural composites, evolved the idea of developing Artificial Composites, which are widely used nowadays.

In general composite materials are combinations of materials put together to achieve a particular function. The combinations may be materials of the same class or of different class. The fibres are the principal load-carrying members, while the surrounding matrix keeps them in the desired location and orientation, acts as a load 
transfer medium between them and protects them from environmental damages due to elevated temperatures and humidity.

According to Mallick (1991), a composite material is a combination of two or more chemically different materials with a distinct interface between them. The constituent materials maintain their separate identities in the composite and their combination produces properties and characteristics that are different from those of the constituents.

Gowda et. al (1999) observed that, the main reason for the interest in FRP (fibre reinforced plastic) is due to their high specific modulus, high stiffness to weight ratio and high strength to weight ratio compared to conventional materials. The higher specific modulus and specific strength of composite materials means that the weight of components can be reduced. This is a factor of great importance in moving components especially in all forms of transport where reduction in weight result in greater efficiency and energy saving.

Polymer matrix composites (PMC) are fibre-reinforced polymers in which either a thermoset or a thermoplastic polymer is used as the matrix. According to Stinchcomb (1990) the development of PMCs for structural applications started in the 1950s, and they are the most common fibre-reinforced composite in use today. One reason for their growing use is that their processing method is relatively simple and does not require very high temperatures and pressures. The equipment required for processing PMCs is also relatively simple and less expensive than that required for other types of composites 
The thernoplastics soften upon heating and can be reshaped with heat and pressure. Thermoplastic polymers used for composites include polypropylene, polyvinyl chloride, nylon, polyurethane, poly-ether-ether-ketone (PEEK), polyphenylene sulfide (PPS) and polusulfone. The thermoplastic composites offer the potential for the higher toughness and high volume, low cost processing. They have a useful temperature range upwards of $225^{\circ} \mathrm{C}$, (Herakovich, 1998).

Thermoset polymers become cross-linked during fabrication and do not soften upon reheating. The most common thermoset polymer matrix materials are polyesters, epoxies and polyimides. Polyesters are used extensively with glass fibres. They are inexpensive, lightweight, have a useful temperature range up to $100^{\circ} \mathrm{C}$ and are somewhat resistant to environmental exposures. Epoxies are more expensive but have better moisture resistance and lower shrinkage on curing. They can withstand a maximum temperature in the vicinity of $175^{\circ} \mathrm{C}$. Polyimides can withstand a higher temperature $300^{\circ} \mathrm{C}$ but are more difficult to fabricate (Herakovich, 1998).

According to Mall (1990), graphite fibres (carbon) are lighter than glass fibres, and therefore they are preferred in applications where fatigue and weight are of primary concern such as in aerospace applications. Some of the attributes of carbon fibres such as high specific strength and stiffness, low coefficient of thermal expansion and low abrasion, biological and chemical inertness, X-ray permeability, fatigue resistance, self-lubrication, high damping, high corrosion resistance, and electrical conductivity are significant in the selection of fibre as reinforcement. There are three main routes for producing carbon fibres; namely, orientation of polymer 
precursor by stretching, orientation by spinning and orientation during carbonisation and graphitisation.

Oil palm fruit bunch fibre is a non-hazardous biodegradable material extracted from oil palm's vascular bundles in the empty fruit bunch through a patented (MY304644-A) decortation process. The fibres are clean, non-carcinogenic, free from pesticides and almost free from soft parenchyma cells, (Sabutek 2002). According to Ridzuan et. al (2002) oil palm fruit bunch fibre can be used as filler in plastic to reduce its cost, where plastic on the other hand is increasingly expensive especially with the high petroleum price. Gowda et. al (1999) also found that natural fibre composites possess better electrical resistance, good thermal and acoustic insulating properties and higher resistance to fracture.

Understanding the material behaviour is fundamental to the design of new products, especially when using complex materials such as composites. There are only limited research works being carried out on oil palm fruit bunch fibre. In order to promote the use of this material, there must be sufficient information of the material especially on the mechanical properties and its fatigue behaviour. The mechanical properties and fatigue behaviour of composites can vary significantly with factors such as temperature, load rate, pre-cycling and environmental exposure, (Mallick, 1991). In order to determine the mechanical and physical properties of the material several tests should be conducted and among them are tensile, compression, bending and fatigue tests. 
Hull (1981) has defined Fatigue as the ultimate failure of a material or component by the application of a varying load whose maximum amplitude, if continuously applied, is insufficient to cause failure. According to Mallick (1998), the fatigue properties of a material represent its response to cyclic loading, which is a common occurrence in many practical applications. It is well recognised that the strength of a material is significantly reduced under cyclic loads. The cycle to failure depends on a number of variables, such as stress level, stress state, mode of cycling, process history, material composition and environmental conditions. The key point is that the loads must change with time in order to have "fatigue" as described above.

The results of fatigue tests are typically presented as a plot of applied stress against number of cycles to failure. This graph is called an S-N curve as shown in Figure 1.1. This diagram is obtained by testing a number of specimens at various stress levels under certain loading conditions. The ordinate is generally the stress or strain amplitude or the maximum applied stress or strain in a cycle and is plotted on a linear scale. The abscissa is the number of cycles to failure for a fixed stress cycle and is plotted on a logarithmic scale.

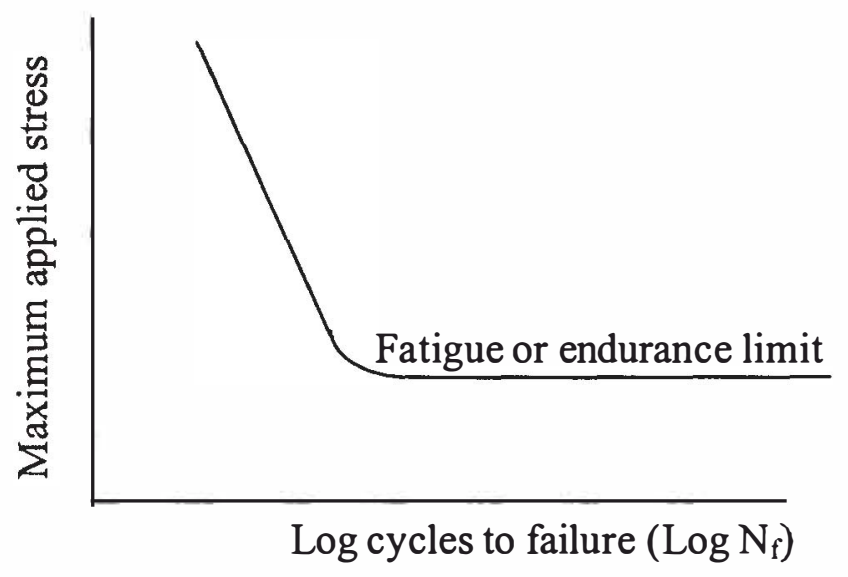

Figure 1.1: A Typical S-N curve 
The damage in composites due to fatigue is limited to a range of stress. This phenomenon is known as the endurance or fatigue limit, shown schematically in Figure 1.1. The slope of the S-N curve is a measure of the resistance of the material to fatigue and the actual shape varies from one material to another. For a majority of materials, the cycle to failure increases continuously as the stress level is reduced (Mallick, 1988).

Fracture of components due to fatigue is the most common type of in service failure. Particularly in shafts, axles, aircraft wings, where cyclic stressing is taking place. This makes fatigue a widespread phenomenon in technological society nowadays, where countless devices, from the space shuttle to many children's toys, are subjected to loads whose amplitudes and forms change with time.

Fatigue failures can and often do occur under loading conditions where the fluctuating stress is below the tensile strength and, in some materials, even below the elastic limit. Because of its importance, the subject has extensively being studied over the past one hundred years but even today one still occasionally hears of the disaster in which fatigue is a prime contributing factor.

In general there are three primary fatigue analysis methods, which are usually used by researchers (Bannantine et. al, 1990). They are the stress-life, the strain-life and the fracture mechanics approaches. These methods have their own region of application with some degree of overlapping. The understanding of any of these methods provides a technique, which may be used to perform a fatigue analysis. However it is the insights gained from the understanding of all three methods, which 